\title{
Research Trends Analysis on Subject Materials Science for Energy Engineering by Scopus Data
}

\author{
Boris N. Chigarev \\ Oil and Gas Research Institute of RAS \\ Moscow,Russia,bchigarev@ipng.ru
}

\begin{abstract}
$\underline{\text { ABSTRACT }}$
The objective of this article: analysis of research trends on the topic "Materials Science for Energy Engineering" for the period 2012-2021.

Materials and methods: bibliometric analysis of data from the Scopus abstract database.

Results. It is shown that this topic is developing faster than the general energy topics.

The key feature of the research trends is a significant increase in work on the development of materials for renewable energy and a decrease in the number of publications related to nuclear power.

The primary goal of many studies is to increase the efficiency of renewable energy production through the use of new materials.

The importance of the topic is evidenced by the emergence of new journals that quickly entered the first quartile of the abstract databases Scopus and Web of Science, for example: ACS Applied Energy Materials.

There has been a significant increase of interest in perovskite solar cells, layered semiconductors, triboelectric nanogenerators, cobalt compounds, sulfur compounds, and oxygen and hydrogen evolution reaction during Electrolysis. Publications on electric batteries are well represented in all time intervals. The focus is on electrode materials and battery efficiency.
\end{abstract}

Keywords: research topics, materials science, energy, Scopus, bibliometric analysis, trends, keyword clustering

Introduction 
The purpose of this work was:

- To analyze the significance of research on materials science for energy engineering according to the metadata of publications in the Scopus abstract database.

- To identify the major research trends in scientific publications on the specified topic based on keyword occurrence analysis.

- To demonstrate some methods of bibliometric analysis to solve the above tasks.

The relevance of the work is due to the ongoing energy transition to clean energy in all developed countries [1-3], supported by both well-funded national programs and international organizations, including the UN. ${ }^{1}$

Moreover, the energy transition is an essential component in the ongoing change in the economic paradigm [4-6] and forms new, fast-growing markets, the development of which requires a wide range of research works, the significance of which can be assessed using the metadata available in the leading abstract databases.

In the abstract databases of scientific publications, research related to the energy transition is most often classified under the subject categories "Renewable Energy Sustainability and the Environment". ${ }^{2}$

By analyzing the bibliometric data, it is possible to understand what scientific and engineering tasks are the most relevant for implementing of the energy transition to clean and affordable energy and what participation Russian researchers can take in their solution.

Such an analysis can be implemented using the metadata of the leading abstract databases Scopus, Web of Science, and the Lens. In this article, we mainly used the materials of the Scopus platform, which provides not only access to metadata but also to a significant number of full-text articles published by Elsevier. To reduce bias in our analysis, we will partially use data from the Lens database, in which the categorization of publication metadata by Fields of Study is close to the

\footnotetext{
1 https://sdgs.un.org/goals/goal7 - Ensure access to affordable, reliable, sustainable and modern energy for all

2 https://www.elsevier.com/catalog?page=26\&cat0=energy \&cat1=renewable-energy-sustainability-and-the-environment and https://www.lens.org/lens/search/scholar/list?p=0\&subject.must=Renewable\%20Energy, \%20Sustainability $\% 20$ and $\% 20$ the $\% 20$ Environment
} 
categorization on the Scopus platform. It is convenient to use the data of this platform as complementary to the data of the Scopus system.

In the Lens, the subject category "Renewable Energy, Sustainability and the Environment" contains bibliometric data on 299,373 Scholarly Works (as of 03.03.2021). Table 1 shows the distribution of publications by the 20 most frequent Fields of Study values for the time interval 2012-2021.

Таблица 1. Основные значения поля Fields of Study за 2012-2021 гг. по теме "Возобновляемая энергетика, устойчивое развитие и окружающая среда" по данным платформы the Lens

Table 1. Top Fields of Study for 2012-2021 for "Renewable Energy, Sustainability and the Environment" subject by the Lens platform data

Doc

\begin{tabular}{|c|c|c|c|}
\hline Field of Study & Count & Field of Study & Count \\
\hline Materials science & 99475 & $\begin{array}{l}\text { Waste manage- } \\
\text { ment }\end{array}$ & 16036 \\
\hline Chemistry & 49385 & Electrochemistry & 15755 \\
\hline $\begin{array}{l}\text { Chemical engineer- } \\
\text { ing }\end{array}$ & 43525 & Renewable energy & 15231 \\
\hline $\begin{array}{l}\text { Environmental sci- } \\
\text { ence }\end{array}$ & 37380 & Sustainability & 14728 \\
\hline Engineering & 25962 & Biomass & 13262 \\
\hline Business & 20064 & Electrode & 12917 \\
\hline Catalysis & 19503 & Electrolyte & 12532 \\
\hline Inorganic chemistry & 19412 & $\begin{array}{l}\text { Photovoltaic sys- } \\
\text { tem }\end{array}$ & 11233 \\
\hline Nanotechnology & 16545 & Optoelectronics & 11211 \\
\hline Computer science & 16303 & Anode & 11154 \\
\hline
\end{tabular}

The Fields of Study "Materials science" dominates in the above subject area in the publications indexed by the Lens platform, which indicates its importance in solving engineering problems of the energy transition as well. [7-9].

This is mostly because of the importance of creating energy storage facilities for renewable energy. California's August 2020 electric "green blackouts" are a reminder that without clean energy storage, utilities are forced to enter spot markets for electricity produced from traditional sources. Without energy storage, new technologies cannot fully replace old ones. [10,11] 
The relevance of Materials science topics is confirmed even by the names of journals related to the subject "Renewable Energy, Sustainability and the Environment" and included in Q1, as by Scimagojr.com. Examples of such journals are given in Table 2.

\section{Таблица 2. Список ведущих журналов по теме «Materials science for energy engineer- ing»}

Table 2. List of leading journals on materials science for energy engineering

\begin{tabular}{cccc} 
Title & SJR & SJR Quartile & H index \\
\hline Advanced Energy Materials & 9,513 & Q1 & 186 \\
Energy Storage Materials & 5,044 & Q1 & 54 \\
Journal of Materials Chemistry A & 3,432 & Q1 & 185 \\
Solar Energy Materials and Solar Cells & 1,827 & Q1 & 178 \\
Materials Today Energy & 1,653 & Q1 & 22 \\
Sustainable Materials and Technologies & 1,355 & Q1 & 18
\end{tabular}

Here: SJR - The SCImago Journal Rank indicator ${ }^{3}$. The very titles of the journals themselves testify to the importance of materials science in solving the problems of energy engineering.

\section{Materials and methods}

Bibliometric materials for a detailed analysis of trends in publication activity on the topic Material Science for Industrial Energy were selected from the Scopus database. In the Scopus there are thematic filters "Subject Areas", allowing to form an actual query to a database, in our case filters Materials Science, Energy, Engineering and restriction on years of publication 2012-2021 were used. An additional filter Engineering was used to narrow the sample, for example, to exclude works closer to environmental or economic problems.

Query: SUBJAREA (ener) AND SUBJAREA (mate) AND SUBJAREA (engi) AND PUBYEAR > 2011 AND (LIMIT-TO (PUBSTAGE, "final") AND (LIMIT-TO (DOCTYPE, "ar")) AND (LIMIT-TO (LANGUAGE, "English")) returned 28,674 document results. The query used additional restrictions to make the

\footnotetext{
${ }^{3}$ https://en.wikipedia.org/wiki/SCImago_Journal_Rank
} 
sample more homogeneous and suitable for further analysis: language - English, document type - article ("ar"), publication status - "final".

The distribution of articles by year is as follows - YEAR (Doc count): 2021 (889); 2020 (5039); 2019 (4462); 2018 (4034); 2017 (3176); 2016 (2615); 2015 (2741); 2014 (2198); 2013 (1929); 2012 (1591).

The ratio of publications in 2020 vs 2012 is 3.17, which is slightly higher than the total increase in the number of publications in the Scopus database for these years for the entire energy subject - 2.6, indicating the relevance of our formulated query.

In addition to the frequency of occurrence of Fields of Study, keywords, and the number of publications in leading journals on the subject in question, this article studied the clustering of authors' and index keywords based on their co-occurrence. The clustering of terms makes it possible to distinguish topics within the collected bibliometric data. This procedure was performed using the VOSViewer software [12]. a software tool for constructing and visualizing bibliometric networks, to cluster terms based on their co-occurrence.

For detailed bibliometric analysis, all data from Scopus for 2021, 2013 and 2012 were exported, for 2014-2020 - 2,000 most cited articles (limitation imposed by Scopus on data export) totaling 18,409 articles. For the general analysis, the files "Scopus_exported_refine_values" were used, which contain summary data for the entire sample, including SUBJECT AREA and SOURCE TITLE fields.

Results and Discussion

Table 3 shows the major SUBJECT AREA and SOURCE TITLE for all 28674 publications matching the query SUBJAREA (ener) AND SUBJAREA (mate) AND SUB-JAREA (engi) AND PUBYEAR> 2011 AND (LIMIT-TO (PUBSTAGE, "final") AND (LIMIT-TO (DOCTYPE, "ar")) AND (LIMIT-TO (LANGUAGE, "English")).

Таблица 3. 12 основных предметных областей исследований и названий журналов по данным всех 28674 публикаций

Table 3. Top 12 subject areas and journal titles for all 28674 publications' data

\begin{tabular}{llll} 
SUBJECT AREA & N & SOURCE TITLE & N \\
\hline Energy & 28674 & Nano Energy & 5295 \\
Engineering & 28674 & Fusion Engineering and Design & 4759 \\
Materials Science & 28674 & Nuclear Engineering and Design & 4057
\end{tabular}




\begin{tabular}{|c|c|c|c|}
\hline Physics and Astronomy & 9431 & ACS Applied Energy Materials & 3159 \\
\hline Chemical Engineering & 5149 & $\begin{array}{l}\text { Physica C Superconductivity and Its Ap- } \\
\text { plications }\end{array}$ & 1689 \\
\hline Environmental Science & 4946 & $\begin{array}{l}\text { Progress in Photovoltaics Research and } \\
\text { Applications }\end{array}$ & 1080 \\
\hline Chemistry & 3938 & Industrial Lubrication and Tribology & 1025 \\
\hline $\begin{array}{l}\text { Biochemistry, Genetics and Molecu- } \\
\text { lar Biology }\end{array}$ & 1556 & Fusion Science and Technology & 854 \\
\hline Computer Science & 1339 & Solar RRL & 795 \\
\hline Mathematics & 656 & $\begin{array}{l}\text { Springerbriefs in Applied Sciences and } \\
\text { Technology }\end{array}$ & 656 \\
\hline $\begin{array}{l}\text { Business, Management and Ac- } \\
\text { counting }\end{array}$ & 398 & Pipeline and Gas Journal & 636 \\
\hline Medicine & 386 & High Technology Letters & 569 \\
\hline
\end{tabular}

Energy; Engineering; Materials Science - are database query filters, so these topics apply to all 28674 publications.

Chemical Engineering, Chemistry, Environmental Science, and Computer Science are close in meaning to the data in Table 1. Although the classification is based on data from various abstract platforms. The Engineering filter was chosen to emphasize engineering tasks. If filters Chemical Engineering and Chemistry had been used, we would have received a different cross-section of data, but also relevant to the topic "Materials Science for Energy".

Table 4 presents the results of the analysis of trends in topic trends based on the distribution of author and index keywords (Author Keywords and Index Keywords fields) by year. Only the years 2014-2020 were considered, due to the strong change in keyword distribution in the years (2012-2013) compared to the years 20142020. Notations in the table: KeyWord = Author Keywords + Index Keywords, N number of publications by year.

Таблица 4. Распределение ключевых слов, встречающихся во всех публикациях за 2014-2020 годы, получено как внутреннее соединение исходных годовых таблиц Table 4. The distribution of keywords that occur in all publications for 2014-2020 is got as the inner join of the year-by-year tables

\begin{tabular}{llllllll} 
KeyWord & N 2020 & N 2019 & N 2018 & N 2017 & N 2016 & N 2015 & N 2014 \\
\hline Efficiency & 332 & 298 & 233 & 118 & 119 & 71 & 32 \\
Lithium Compounds & 299 & 231 & 216 & 82 & 77 & 72 & 23 \\
Electrodes & 269 & 224 & 240 & 246 & 196 & 171 & 46
\end{tabular}




$\begin{array}{llllllll}\text { Electrolytes } & 264 & 209 & 176 & 106 & 102 & 63 & 23 \\ \text { Cathodes } & 254 & 220 & 173 & 69 & 59 & 48 & 25 \\ \text { Anodes } & 229 & 216 & 159 & 82 & 65 & 67 & 43 \\ \text { Ions } & 215 & 226 & 204 & 115 & 99 & 76 & 26 \\ \text { Electrochemical Performance } & 201 & 143 & 119 & 58 & 42 & 52 & 36 \\ \text { Open Circuit Voltage } & 197 & 160 & 126 & 70 & 54 & 61 & 26 \\ \text { Thin Films } & 162 & 122 & 138 & 74 & 63 & 72 & 41 \\ \text { Carbon } & 161 & 147 & 137 & 90 & 88 & 98 & 31 \\ \text { Graphene } & 160 & 160 & 132 & 72 & 81 & 97 & 39 \\ \text { Nanotechnology } & 154 & 133 & 61 & 92 & 53 & 60 & 34 \\ \text { Energy Harvesting } & 151 & 170 & 86 & 72 & 40 & 35 & 18 \\ \text { Solar Cells } & 149 & 227 & 266 & 216 & 220 & 215 & 92 \\ \text { Titanium Dioxide } & 145 & 120 & 136 & 39 & 43 & 31 & 19 \\ \text { Electric Discharges } & 140 & 131 & 96 & 81 & 71 & 50 & 29 \\ \text { Lithium } & 136 & 87 & 107 & 176 & 130 & 122 & 53 \\ \text { Silicon } & 136 & 57 & 54 & 55 & 58 & 76 & 48 \\ \text { Scanning Electron Microscopy } & 132 & 120 & 123 & 55 & 60 & 53 & 48 \\ \text { Hydrogen } & 129 & 94 & 76 & 64 & 49 & 49 & 42 \\ \text { Magnetoplasma } & 123 & 169 & 125 & 160 & 111 & 89 & 50 \\ \text { Tokamak Devices } & 120 & 164 & 130 & 163 & 116 & 92 & 65 \\ \text { Nanoparticles } & 114 & 137 & 128 & 63 & 81 & 64 & 42\end{array}$

For the keywords Efficiency, Lithium Compounds, Electrolytes, Cathodes, there is an increase in the number of publications by over 10 times for 7 years and this despite the fact that the filter was Engineering not Chemical Engineering. The frequency of the keywords Solar Cells, Lithium, Tokamak Devices, Nanoparticles passed the stage of intensive growth.

A number of terms that occur frequently in publications in 2020 did not occur in the first 160 keywords in 2014 and 2015 and rarely in 2016, so we present them separately, comparing the occurrence in 2016 and 2020. The results for the $22 \mathrm{key}-$ words that either rarely or not at all occur in 2016 but are widely used in 2020 are presented in Table 5.

Таблица 5. Список терминов, которые часто встречаются в 2020 году и редко или совсем не встречаются в 2016 году

Table 5. List of terms that occur frequently in 2020 and rarely or not at all in 2016

\begin{tabular}{llllll} 
KeyWord & N 2020 & N 2016 & KeyWord & N 2020 & N 2016 \\
\hline Perovskite & 437 & 65 & Electrochemical Electrodes & 132 & null \\
Perovskite Solar Cells & 342 & 52 & II-VI Semiconductors & 131 & null \\
Nanogenerators & 190 & null & High Energy Densities & 128 & null
\end{tabular}




$\begin{array}{llllll}\text { Solid Electrolytes } & 173 & \text { null } & \text { Oxygen Evolution Reaction } & 115 & \text { null } \\ \text { Sulfur Compounds } & 169 & \text { null } & \text { Triboelectric Nanogenerator } & 112 & \text { null } \\ \text { Binary Alloys } & 167 & \text { null } & \text { Electron Transport Properties } & 111 & \text { Null } \\ \text { Morphology } & 163 & \text { null } & \text { Organic Solar Cells } & 109 & \text { Null } \\ \text { Lead Compounds } & 154 & \text { null } & \text { Lithium Batteries } & 108 & \text { Null } \\ \text { Nickel Compounds } & 152 & \text { null } & \text { Solid-State Batteries } & 107 & \text { Null } \\ \text { Supercapacitor } & 149 & \text { null } & \text { Copper Compounds } & 107 & \text { Null } \\ \text { Cobalt Compounds } & 136 & \text { null } & \text { Oxide Minerals } & 106 & \text { Null }\end{array}$

There is a significant increase in interest in the topic described by the keywords Perovskite, Perovskite Solar Cells. The terms Nanogenerators and Triboelectric Nanogenerator did not appear in the top 160 keywords in 2016, and in 2020 the total number of occurrences of the term Nanogenerator and Triboelectric Nanogenerator reached 302 .

The keywords containing the term Compound, which, unlike Lithium Compounds, did not appear in the top 160 keywords in 2016, are noteworthy: Sulfur Compounds (169), Lead Compounds (154), Nickel Compounds (152), Cobalt Compounds (136), Copper Compounds (107), Iron Compounds (103), Fluorine Compounds (93), Chlorine Compounds (91), Manganese Compounds (91), Selenium Compounds (88), Bismuth Compounds (76), Molybdenum Compounds (74), Zinc Compounds (74), Titanium Compounds (70), Bromine Compounds (69), Tin Compounds (68), Silicon Compounds (67), Sodium Compounds (66). Data format - keyword (occurrence in 2020).

The evolution of the general topic of the publications estimated by the Scopus query considered in the article can also be assessed by the number of publications in different journals. Table 6 shows the data for 10 highly cited journals well reflecting various aspects of research on materials science for energy.

Таблица 6. Десять ведущих журналов по публикационной активности в 2020 и 2016 годах

Table 6. Top 10 journals by publication activity in 2020 and 2016

\begin{tabular}{ccc} 
Source Title & N 2020 & N 2016 \\
\hline ACS Applied Energy Materials & 1330 & null \\
Nano Energy & 1020 & 579 \\
Fusion Engineering and Design & 628 & 634 \\
Nuclear Engineering and Design & 430 & 431 \\
Solar RRL & 297 & null
\end{tabular}




$\begin{array}{ccc}\text { Industrial Lubrication and Tribology } & 124 & 91 \\ \text { Fusion Science and Technology } & 119 & 49 \\ \text { Physica C Superconductivity and Its Applications } & 113 & 145 \\ \text { Molecular Systems Design and Engineering } & 111 & 26 \\ \text { Progress in Photovoltaics Research and Applications } & 107 & 128\end{array}$

The increasing interest in the topic discussed in this article is confirmed by publications in ACS Applied Energy Materials, a Q1 journal published by the American Chemical Society, indexed by Scopus and WoS since 2018. The total number of journal publications in 2020 according to Scopus is 1364, of which 1330 satisfy our request.

Solar RRL is also not yet published in 2016 (previously published as Rapid Research Letters), but is now included in Q1 WoS and Scopus, with 297 of the 411 publications for 2020 included in our sample.

Nano Energy - for 5 years the number of publications increased from 579 to 1020 , which indicates the growth of interest in nanotechnology in obtaining materials for energy.

In the journals Fusion Engineering and Design, Nuclear Engineering and Design, Physica C Superconductivity and Its Applications, and Progress in Photovoltaics Research and Applications, the publication activity in the subject we analyzed has not increased.

To assess the overall trend in changes in publication topics over the entire study period, a comparison (INNER JOIN) of the 1,000 most frequently used keywords between 2012-2016 and 2017-2021 was conducted; Table 7 shows the 45 terms with the highest growth over the period.

\section{Таблица 7. Ключевые слова с наибольшим темпом роста встречаемости в 2012-2016 и} 2017-2021 годах

Table 7. Key words with the highest rate of increase in occurrence during 2012-2016 and 2017-2021

\begin{tabular}{|c|c|c|c|c|c|}
\hline KeyWord & gain & KeyWord & gain & KeyWord & gain \\
\hline nanogenerators & 17.94 & bismuth compounds & 6.50 & organic polymers & 5.07 \\
\hline $\begin{array}{l}\text { layered semiconduc- } \\
\text { tors }\end{array}$ & 15.44 & $\begin{array}{c}\text { metal organic frame- } \\
\text { work }\end{array}$ & 6.50 & chemical stability & 5.05 \\
\hline perovskite solar cells & 11.74 & ii-vi semiconductors & 6.46 & silicon compounds & 5.00 \\
\hline $\begin{array}{l}\text { oxygen evolution re- } \\
\text { action }\end{array}$ & 9.11 & solid electrolytes & 6.27 & long term stability & 4.92 \\
\hline
\end{tabular}




\begin{tabular}{|c|c|c|c|c|}
\hline triboelectricity & 8.62 & iron compounds & 6.26 & theoretical calculations \\
\hline perovskite & 8.45 & hole mobility & 6.00 & cell engineering \\
\hline cobalt compounds & 8.18 & positive ions & 5.95 & redox reactions \\
\hline binary alloys & 7.69 & $\begin{array}{l}\text { molybdenum com- } \\
\text { pounds }\end{array}$ & 5.91 & electrocatalyst \\
\hline sulfur compounds & 7.64 & coulombic efficiency & 5.82 & $\begin{array}{l}\text { solid electrolyte inter- } \\
\text { phase }\end{array}$ \\
\hline $\begin{array}{l}\text { triboelectric nanogen- } \\
\text { erator }\end{array}$ & 7.55 & $\begin{array}{l}\text { hydrogen evolution re- } \\
\text { actions }\end{array}$ & 5.69 & $\begin{array}{l}\text { thermo-electric materi- } \\
\text { als }\end{array}$ \\
\hline sodium-ion batteries & 7.00 & molecules & 5.54 & fullerenes \\
\hline sodium compounds & 6.84 & selenium compounds & 5.35 & electrolysis \\
\hline zinc compounds & 6.82 & $\begin{array}{l}\text { density functional the- } \\
\text { ory }\end{array}$ & 5.34 & transition metals \\
\hline $\begin{array}{l}\text { hydrogen evolution } \\
\text { reaction }\end{array}$ & 6.52 & charge recombinations & 5.18 & $\begin{array}{l}\text { power conversion effi- } \\
\text { ciencies }\end{array}$ \\
\hline organic solar cells & 6.50 & morphology & 5.17 & flexible electronics \\
\hline
\end{tabular}

The frequency of keywords nanogenerators, layered semiconductors, perovskite solar cells, oxygen evolution reaction, triboelectricity, perovskite, cobalt compounds, binary alloys, sulfur compounds, triboelectric nanogenerator, sodium-ion batteries have increased by 7 times or more during this period, which corresponds well with the results of Table 5. It should be highlighted that the diversity in the composition of samples for the construction of Tables 4, 5, 7 provides different slices of raw data, which makes the picture of changes in the topics of publications more diverse and sustainable.

The data in Table 7 can be helpful for a more detailed study of the dynamics of publication activity on more specific issues. For example, a precise query to the Scopus database: TITLE-ABS-KEY ("hydrogen evolution reaction") returns 14,608 document results, with only 121 papers published in 2012 and 3,125 in 2020. This means that the topic of "hydrogen evolution reaction" is developing rapidly and in a broader context than that of this article: Materials Science for Energy Engineering and, consequently, the work in this direction may be in high demand. In [13] an excellent overview of this topic is given.

In order to identify possible emerging topics for which keywords are still present in a few of publications, but whose occurrence growth is very high, it is necessary to maximize the list of keywords compared over the two periods under 
consideration. Table 8 shows the terms that are rarely encountered, but are growing rapidly, according to the results of the analysis of 16,943 keywords.

Таблица 8. 30 самых быстрорастущих ключевых слов из списка 16943 ключевых слов. Здесь $\mathbf{N}_{n}$ и $\mathbf{N}_{\text {o, }}$ соответственно, - количество публикаций за более новый и более ранний периоды

Table 8. Top 30 Fastest-Growing keywords from the list of 16943 keywords. Here $\mathbf{N}_{\mathbf{n}}$ and $N_{0}$, respectively, are the number of publications for the newer and earlier periods

\begin{tabular}{llllllll} 
KeyWord & $\mathbf{N}_{\mathbf{n}}$ & $\mathbf{N}_{\mathbf{o}}$ & gain & KeyWord & $\mathbf{N}_{\mathbf{n}}$ & $\mathbf{N}_{\mathbf{o}}$ & gain \\
\hline Crystallinity & 120 & 4 & 30.00 & metal-organic frameworks & 60 & 4 & 15.00 \\
photocatalytic activity & 110 & 4 & 27.50 & reaction intermediates & 55 & 4 & 13.75 \\
lead compounds & 329 & 13 & 25.31 & mxene & 40 & 3 & 13.33 \\
wearable sensors & 96 & 4 & 24.00 & design for testability & 66 & 5 & 13.20 \\
ionic conductivity & 67 & 3 & 22.33 & ammonia & 79 & 6 & 13.17 \\
nickel compounds & 264 & 13 & 20.31 & chromium compounds & 39 & 3 & 13.00 \\
Nanogenerators & 556 & 31 & 17.94 & x ray scattering & 38 & 3 & 12.67 \\
hole transport layers & 71 & 4 & 17.75 & nanocatalysts & 75 & 6 & 12.50 \\
manganese compounds & 153 & 9 & 17.00 & faradaic efficiencies & 62 & 5 & 12.40 \\
image enhancement & 49 & 3 & 16.33 & oxygen vacancies & 99 & 8 & 12.38 \\
triboelectric nanogenerators & 65 & 4 & 16.25 & tio2 nanoparticles & 37 & 3 & 12.33 \\
electron transport layers & 126 & 8 & 15.75 & phosphorus compounds & 107 & 9 & 11.89 \\
layered semiconductors & 247 & 16 & 15.44 & small molecules & 47 & 4 & 11.75 \\
carbon nitride & 77 & 5 & 15.40 & sodium-ion battery & 47 & 4 & 11.75 \\
potassium hydroxide & 122 & 8 & 15.25 & perovskite solar cells & 716 & 61 & 11.74
\end{tabular}

The degree of structural ordering of the material (crystallinity), photocatalytic activity, lead compounds and wearable sensors (a topic for medicine rather than energy, but new materials are needed to convert human activity into energy for such sensors) these may prove to be promising new research challenges.

Trends in research topics can also be assessed by comparing keywords that occur only in the metadata of publications for 2017-2021 but do not occur in 20122016, and vice versa. To limit the sample, a keyword occurrence threshold of 10 was used and then the 30 most frequent keywords in publications over the period were selected from these words. Tables 9 and 10 show the main keywords and their occurrence rate for the first and second cases, respectively.

Таблица 9. 30 ключевых слов, которые наиболее часто появляются в новых публикациях, но не преодолели порог в 10 повторений в более ранний период 
Table 9. Top 30 Keywords that appear frequently in new publications but did not pass the 10-occurrence threshold in an earlier period

\begin{tabular}{llllll} 
KeyWord & N & KeyWord & N & KeyWord & N \\
\hline manganese compounds & 153 & iodine compounds & 89 & aluminum compounds & 66 \\
solid-state batteries & 150 & output performance & 79 & design for testability & 66 \\
electron transport layers & 126 & ammonia & 79 & triboelectric nanogenerators & 65 \\
potassium hydroxide & 122 & carbon nitride & 77 & halide perovskites & 64 \\
crystallinity & 120 & antimony compounds & 76 & co2 reduction & 63 \\
bromine compounds & 113 & alkalinity & 76 & silver compounds & 63 \\
photocatalytic activity & 110 & nanocatalysts & 75 & faradaic efficiencies & 62 \\
phosphorus compounds & 107 & ruthenium compounds & 72 & nitrogen compounds & 61 \\
oxygen vacancies & 99 & hole transport layers & 71 & metal-organic frameworks & 60 \\
wearable sensors & 96 & ionic conductivity & 67 & solid state devices & 59
\end{tabular}

Таблица 10. 30 ключевых слов, которые наиболее часто появляются в старых публикациях, но не преодолели порог в 10 повторений в более позднем периоде

Table 10. Top 30 keywords that appear frequently in older publications, but did not pass the 10-occurrence threshold at a later period

\begin{tabular}{|c|c|c|c|c|c|}
\hline KeyWord & $\mathbf{N}$ & KeyWord & $\mathbf{N}$ & KeyWord & $\mathbf{N}$ \\
\hline experiments & 208 & critical currents & 61 & $\begin{array}{l}\text { austenitic } \\
\text { steel }\end{array}$ & 44 \\
\hline super capacitor & 113 & room temperature & 59 & $\begin{array}{l}\text { josephson junction de- } \\
\text { vices }\end{array}$ & 43 \\
\hline algorithms & 110 & $\begin{array}{l}\text { high temperature supercon- } \\
\text { ducting }\end{array}$ & 53 & magnetization & 43 \\
\hline three dimensional & 100 & sodium cooled fast reactor & 52 & high-t & 42 \\
\hline heavy water reactors & 69 & tio & 48 & safety analysis & 41 \\
\hline critical current density & 67 & alloys & 48 & research reactors & 41 \\
\hline experimental data & 65 & zirconium & 45 & $\begin{array}{l}\text { reconfigurable hard- } \\
\text { ware }\end{array}$ & 40 \\
\hline superconducting films & 63 & mathematical models & 45 & cuprates & 39 \\
\hline flow rate & 63 & vapors & 45 & journal bearings & 39 \\
\hline $\begin{array}{l}\text { iron-based supercon- } \\
\text { ductors }\end{array}$ & 62 & lubricating oils & 45 & $\begin{array}{l}\text { superconducting de- } \\
\text { vices }\end{array}$ & 39 \\
\hline
\end{tabular}

The above results on the discovery of trends in scientific publications were mainly based on the analysis of keywords for the query in question. A list of related words can better describe the topic than individual keywords. Words can be clustered using methods based on their co-occurrence. In this paper, keyword clustering was performed using free software VOSviewer [14] (a software tool for constructing and 
visualizing bibliometric co-occurrence networks). Bibliometric data were grouped for three two-year periods - 2015-2016, 2017-2018, and 2019-2020. Each group included 4,000 records, which was sufficient to obtain six stable clusters. Tables 1113 represent each of the 10 keywords and their occurrence for three of the six clusters with the highest number of co-occurring keywords. Each of the tables reflects data for a two-year interval. The most frequent keyword was used as the field name of the corresponding column of the table. This approach allows us to trace the changes in the position of the keyword cluster over time. It should be noted that the order of occurrence and even the 10 terms under consideration change over time in the cluster.

Таблица 11. Три кластера с наибольшим количеством ключевых слов за период 20152016 гг.

Table 11. The three clusters with the highest number of keywords for the 2015-2016 period

\begin{tabular}{|c|c|c|c|c|c|}
\hline solar cells & 418 & electrodes & 355 & nuclear reactors & 193 \\
\hline efficiency & 181 & lithium & 244 & heat transfer & 174 \\
\hline silicon & 130 & electric batteries & 180 & design & 172 \\
\hline thin films & 122 & graphene & 172 & tritium & 155 \\
\hline solar power generation & 120 & carbon & 170 & tokamak devices & 153 \\
\hline open circuit voltage & 113 & ions & 162 & $\begin{array}{l}\text { computational fluid dy- } \\
\text { namics }\end{array}$ & 152 \\
\hline deposition & 101 & electrolytes & 160 & finite element method & 151 \\
\hline silicon solar cells & 95 & $\begin{array}{l}\text { lithium-ion batter- } \\
\text { ies }\end{array}$ & 155 & magnetoplasma & 151 \\
\hline perovskite & 92 & $\begin{array}{l}\text { lithium com- } \\
\text { pounds }\end{array}$ & 149 & heat flux & 150 \\
\hline $\begin{array}{l}\text { power conversion efficien- } \\
\text { cies }\end{array}$ & 92 & $\begin{array}{l}\text { secondary batter- } \\
\text { ies }\end{array}$ & 142 & fuels & 128 \\
\hline
\end{tabular}

In this period, solar cells dominate, and the term perovskite is still quite rare. Nuclear power is well represented in the third cluster.

Таблица 12. Три кластера с наибольшим количеством ключевых слов за период 20172018 гг.

Table 12. The three clusters with the highest number of keywords for the 2017-2018 period

\begin{tabular}{llllll} 
electrodes & $\mathbf{4 1 8}$ & solar cells & $\mathbf{4 0 1}$ & heat transfer & $\mathbf{1 2 4}$ \\
\hline ions & 250 & perovskite & 321 & nuclear reactors & 112 \\
lithium-ion batter- & 236 & efficiency & 277 & breeding blankets & 107 \\
ies & & & &
\end{tabular}
ies 


\begin{tabular}{|c|c|c|c|c|}
\hline electrolytes & 235 & perovskite solar cells & 277 & $\begin{array}{l}\text { computational fluid dy- } \\
\text { namics }\end{array}$ \\
\hline $\begin{array}{l}\text { lithium com- } \\
\text { pounds }\end{array}$ & 231 & $\begin{array}{l}\text { power conversion efficien- } \\
\text { cies }\end{array}$ & 219 & magnetoplasma \\
\hline lithium & 222 & solar power generation & 187 & tokamak devices \\
\hline anodes & 207 & open circuit voltage & 170 & tritium \\
\hline cathodes & 194 & temperature & 166 & fuels \\
\hline electric batteries & 193 & heterojunctions & 157 & $\begin{array}{l}\text { scanning electron micros- } \\
\text { copy }\end{array}$ \\
\hline carbon & 182 & thin films & 157 & thermal conductivity \\
\hline
\end{tabular}

This period is characterized by the fact that the topic of batteries and electrolysis begins to prevail over that of solar cells. Nuclear power remains well expressed in the third cluster, but more attention is paid to the specific task of heat transfer.

\section{Таблица 13. Три кластера с наибольшим количеством ключевых слов на период 2019-2020 гг.}

Table 13. The three clusters with the highest number of keywords for the 2019-2020 period

\begin{tabular}{|c|c|c|c|c|c|}
\hline perovskite & 484 & nanogenerators & 346 & lithium-ion batteries & 322 \\
\hline perovskite solar cells & 399 & triboelectricity & 305 & electrodes & 299 \\
\hline efficiency & 368 & energy harvesting & 247 & lithium compounds & 292 \\
\hline $\begin{array}{l}\text { power conversion effi- } \\
\text { ciencies }\end{array}$ & 333 & nanotechnology & 234 & electrolytes & 285 \\
\hline open circuit voltage & 241 & nanogenerator & 225 & cathodes & 282 \\
\hline solar cells & 222 & $\begin{array}{l}\text { triboelectric nanogen- } \\
\text { erator }\end{array}$ & 195 & anodes & 266 \\
\hline pounds & 191 & cost effectiveness & 139 & ion & 257 \\
\hline stability & 183 & piezo & 104 & graphene & 207 \\
\hline solar power generation & 182 & wearable technology & 98 & $\begin{array}{l}\text { electrochemical perfor- } \\
\text { mance }\end{array}$ & 206 \\
\hline heterojunctions & 179 & fluorine compounds & 91 & solid electrolytes & 176 \\
\hline
\end{tabular}

In the last period under consideration, the topic of nuclear power is no longer included in the first three clusters; this place is now occupied by the topic of batteries and electrolysis. The first cluster is dominated by the specific implementation of solar panels - perovskite solar cells. The term perovskite appears 467 times in 2020 and 102 times in 2017, a fourfold increase in the number of publications containing the term perovskite over four years. Во втором кластере начинает доминировать новая тема - triboelectric nanogenerator. 
Таким образом, выявлена нарождающаяся тема triboelectric nanogenerator, которая может представлять интерес для дальнейших исследований как для специалистов в области материаловедения и инженерных решений, так и для электропитания носимых датчиков, см. таблицу 8.

The decrease in attention to the topic of materials science for nuclear energy can be explained by the fact that the main funding in the EU, USA and China is aimed at the development of renewable energy. This emphasizes that bibliometric studies are a good reflection of political and economic interests in R\&D. It should be noted that in recent years the term renewable energy has been increasingly replaced by clean energy, which includes nuclear energy.

\section{Summary and Conclusions}

The topic "Materials Science for Energy Engineering" considered in the article has been steadily developing during the whole period under study, which is reflected in the bibliometric data of scientific publications. The great attention paid to the development of renewable energy is reflected in the fact that there is a significant increase in the number of studies on materials engineering for clean energy tasks, so this topic may have a good prospect for investment in this area of R\&D. Emerging areas of research have been identified, an example of this is the triboelectric nanogenerator. The interest in research related to nuclear energy is decreasing - the main funding is going to renewable energy development. The author's private opinion, based not only on the analysis done in this article, is that the production of materials for clean energy is very power-consuming, and in this regard, a sustainable nuclear power industry can be both a reliable energy resource and a base for the development of new materials for clean energy, due to the significant research work done by nuclear industry in previous years, which will allow Russian researchers to take a good position in the global energy world.

\section{References}

1. Sinha, A., Sengupta, T. and Alvarado, R. (2020) 'Interplay between technological innovation and environmental quality: Formulating the SDG policies for next 11 economies', Journal of Cleaner Production. doi: 10.1016/j.jclepro.2019.118549. 
2. Fonseca, L. M., Domingues, P. and Dima, A. M. (2020) 'Mapping the sustainable development goals relationships', Sustainability (Switzerland). doi: 10.3390/SU12083359.

3. Swain, R. B. and Karimu, A. (2020) 'Renewable electricity and sustainable development goals in the EU', World Development. doi: 10.1016/j.worlddev.2019.104693.

4. Mitrova, T. and Melnikov, Y. (2019) 'Energy transition in Russia', Energy Transitions, 3(1), pp. 73-80. doi: 10.1007/s41825-019-00016-8.

5. Mikova, N., Eichhammer, W. and Pfluger, B. (2019) 'Low-carbon energy scenarios 2050 in north-west European countries: Towards a more harmonised approach to achieve the EU targets', Energy Policy, 130, pp. 448-460. doi: https://doi.org/10.1016/j.enpol.2019.03.047.

6. Hafner M., Tagliapietra S. (2020) The Global Energy Transition: A Review of the Existing Literature. In: Hafner M., Tagliapietra S. (eds) The Geopolitics of the Global Energy Transition. Lecture Notes in Energy, vol 73. Springer, Cham. https://doi.org/10.1007/978-3-030-39066-2_1

7. Hirscher, M. et al. (2020) 'Materials for hydrogen-based energy storage - past, recent progress and future outlook', Journal of Alloys and Compounds, 827. doi: 10.1016/j.jallcom.2019.153548.

8. Yan, J. et al. (2020) 'Rational Design of Nanostructured Electrode Materials toward Multifunctional Supercapacitors', Advanced Functional Materials, 30(2). doi: 10.1002/adfm.201902564.

9. Li, Y. et al. (2020) 'Recent Advances on Water-Splitting Electrocatalysis Mediated by Noble-Metal-Based Nanostructured Materials', Advanced Energy Materials. doi: 10.1002/aenm.201903120.

10. Koohi-Fayegh, S. and Rosen, M. A. (2020) 'A review of energy storage types, applications and recent developments', Journal of Energy Storage, 27. doi: 10.1016/j.est.2019.101047.

11. Muralee Gopi, C. V. V. et al. (2020) 'Recent progress of advanced energy storage materials for flexible and wearable supercapacitor: From design and development to applications', Journal of Energy Storage, 27. doi: 10.1016/j.est.2019.101035.

12. van Eck, N. J. and Waltman, L. (2010) 'Software survey: VOSviewer, a computer program for bibliometric mapping', Scientometrics, 84(2), pp. 523-538. doi: 10.1007/s11192-009-0146-3. 
13. Dubouis, N. and Grimaud, A. (2019) 'The hydrogen evolution reaction: From material to interfacial descriptors', Chemical Science, 10(40), pp. 9165-9181. doi: $10.1039 / \mathrm{c} 9 \mathrm{sc} 03831 \mathrm{k}$.

14. van Eck, N. J. and Waltman, L. (2017) 'Citation-based clustering of publications using CitNetExplorer and VOSviewer', Scientometrics, 111(2), pp. 1053-1070. doi: 10.1007/s11192-017-2300-7.

Information about the author. Boris N. Chigarev, Cand. of phys.-math. sci., leading engineer for scientific and technical information. Oil and Gas Research Institute of Russian Academy of Sciences (OGRI RAS). Research interests: Scientometrics, Research trends, Digital and Energy Transition.

ORCID: https://orcid.org/0000-0001-9903-2800

Figshare: https://figshare.com/authors/Boris_Chigarev/6474086 